\title{
Mitotic Catastrophe
}

National Cancer Institute

\section{Source}

National Cancer Institute. Mitotic Catastrophe. NCI Thesaurus. Code C129398.

Programmed cell death that occurs during mitosis caused by various types of cellular damage that lead to the failure of cell cycle checkpoint(s). Micronucleation and multinuceation can occur in cells undergoing this process. 